\title{
A comprehensive review on drug repositioning against coronavirus disease 2019 (COVID19)
}

\author{
Maryam Rameshrad $^{1}$ - Majid Ghafoori ${ }^{2} \cdot$ Amir Hooshang Mohammadpour $^{3,4} \cdot$ Mohammad Javad Dehghan Nayeri $^{5} \cdot$ \\ Hossein Hosseinzadeh ${ }^{6,7}$
}

Received: 21 April 2020 / Accepted: 10 May 2020 / Published online: 19 May 2020

(C) Springer-Verlag GmbH Germany, part of Springer Nature 2020

\begin{abstract}
Severe acute respiratory syndrome coronavirus 2 (SARS-CoV2) is the reason for this ongoing pandemic infection diseases termed coronavirus disease 2019 (COVID-19) that has emerged since early December 2019 in Wuhan City, Hubei Province, China. In this century, it is the worst threat to international health and the economy. After 4 months of COVID-19 outbreak, there is no certain and approved medicine against it. In this public health emergency, it makes sense to investigate the possible effects of old drugs and find drug repositioning that is efficient, economical, and riskless process. Old drugs that may be effective are from different pharmacological categories, antimalarials, anthelmintics, anti-protozoal, anti-HIVs, anti-influenza, antihepacivirus, antineoplastics, neutralizing antibodies, immunoglobulins, and interferons. In vitro, in vivo, or preliminary trials of these drugs in the treatment of COVID-19 have been encouraging, leading to new research projects and trials to find the best $\mathrm{drug} / \mathrm{s}$. In this review, we discuss the possible mechanisms of these drugs against COVID-19. Also, it should be mentioned that in this manuscript, we discuss preliminary rationales; however, clinical trial evidence is needed to prove them. COVID-19 therapy must be based on expert clinical experience and published literature and guidelines from major health organizations. Moreover, herein, we describe current evidence that may be changed in the future.
\end{abstract}

Keywords COVID-19 $\cdot$ Repositioning $\cdot$ SARS-CoV2 $\cdot$ Therapy

$\begin{array}{llll}\text { Abbreviations } & & \text { HIV } & \text { Human immunodeficiency viruses } \\ \text { ACE2 } & \text { Angiotensin-converting enzyme 2 } & \text { IFNs } & \text { Interferons } \\ \text { CoV } & \text { Coronavirus } & \text { IVIg } & \text { Intravenous immunoglobulin } \\ \text { COVID-19 } & \text { Coronavirus disease 2019 } & \text { JAK } & \text { Janus kinase } \\ \text { FDA } & \text { Food and Drug Administration } & \text { MERS } & \text { Middle East respiratory syndrome } \\ \text { HCV } & \text { Hepatitis C virus } & \text { PARP1 } & \text { Poly-ADP-ribose polymerase 1 }\end{array}$

Hossein Hosseinzadeh

hosseinzadehh@mums.ac.ir

Maryam Rameshrad

mrameshrad@gmail.com

Majid Ghafoori

ghafourim841@yahoo.com

Amir Hooshang Mohammadpour

MohamadpoorAH@mums.ac.ir

Mohammad Javad Dehghan Nayeri

DehghanMJ@mums.ac.ir

1 Natural Products and Medicinal Plants Research Center, North Khorasan University of Medical Sciences, Bojnurd, Iran
2 Department of Internal Medicine, School of Medicine, Vector-borne Diseases Research Center, Imam Hassan Hospital, North Khorasan University of Medical Sciences, Bojnurd, Iran

3 Department of Clinical Pharmacy, School of Pharmacy, Mashhad University of Medical Sciences, Mashhad, Iran

4 Pharmaceutical Research Center, Pharmaceutical Technology Institute, Mashhad University of Medical Sciences, Mashhad, Iran

5 Infection Control \& Hand Hygiene Research Center, Mashhad University of Medical Sciences, Mashhad, Iran

6 Department of Pharmacodynamics and Toxicology, School of Pharmacy, Mashhad University of Medical Sciences, Mashhad, Iran

7 Pharmaceutical Research Center, Pharmaceutical Technology Institute, Mashhad University of Medical Sciences, Mashhad, Iran 
RBD Receptor-binding domain

SARS-CoV2 Severe acute respiratory syndrome coronavirus 2

WHO World Health Organization

\section{Introduction}

Coronaviruses are a large family of positive single-stranded RNA viruses (+ssRNA) (Perlman and Netland 2009) and classified into four major genera including alpha- and betacoronaviruses that infect humans and gamma- and deltacoronaviruses that generally infect birds. They are the main reason for respiratory infections and diseases ranging from the common cold to more severe ones. Middle East respiratory syndrome (MERS) - and severe acute respiratory syndrome (SARS)-associated coronavirus belong to the betacoronavirus genus. They are responsible for the recent epidemic worldwide in the recent 20 years. A novel coronavirus (CoV) named "2019 novel coronavirus" or "2019-nCoV", "severe acute respiratory syndrome coronavirus 2", or "SARS-CoV2" has caused the recent pneumonia outbreak named "coronavirus disease 2019" or "COVID-19" since early December 2019 in Wuhan City, Hubei Province, China (Wu et al. 2020) which is now pandemic worldwide.

The pathophysiology and virulence mechanisms of coronaviruses are related to the function of structural and non-structural proteins. Proteases are one of the most important non-structural proteins within the viral replication cycle. They are utilized to produce both functional and structural proteins. Papain-like cysteine protease $\left(\mathrm{PLP}^{\mathrm{pro}}\right)$ and chymotrypsin-like cysteine protease $\left(3 \mathrm{CL}^{\text {pro25-30 }}\right.$ also called $\mathrm{M}^{\text {pro }}$ ) are the main proteases in SARS-CoV (Mukherjee et al. 2011). Interestingly, papain-like cysteine protease can damper the antiviral response of host cells (Lindner et al. 2005; Niemeyer et al. 2018). Helicase and RNA-dependent RNA polymerase are the other crucial non-structural proteins that are encoded by coronaviruses genome (Zumla et al. 2016). The high similarity between the main proteins of SARSCoV and COVID-19 (Zhou et al. 2020), 79.5\% sequence similarity (He et al. 2020), suggests drug designed against these proteins in SARS-CoV (Mukherjee et al. 2011) could be effective against COVID-19, too.

The main structural proteins in coronaviruses include spike (S) glycoprotein, membrane, envelope, and nucleocapsid proteins (Perlman and Netland 2009). Spike glycoproteins on the viral surface are composed of two subunits, $\mathrm{S} 1$ and $\mathrm{S} 2$. The $\mathrm{S} 1$ subunit discovers the virus-host range and cellular tropism by the receptor-binding domain (RBD) and the S2 subunit mediates virus-host cell membrane fusion (Guo et al. 2020; He et al. 2020; Su and Wu 2020). Similar to SARS-CoV, COVID-19 utilizes host cell angiotensin-converting enzyme 2 (ACE2) receptor to enter the cells with a 10 - to 20 -fold higher affinity than SARS$\mathrm{CoV}$ (He et al. 2020; Su and Wu 2020).

The clinical presentation of COVID-19 varies from asymptomatic or paucisymptomatic forms to more severe conditions that need respiratory support, sepsis, septic shock, and multiorgan dysfunction syndrome. The most common sign and symptoms of this disease are fever (98\%), dry cough (76\%), myalgia or fatigue (44\%), and dyspnea (55\%) and the less common symptoms are sputum production $(28 \%)$, headache (8\%), hemoptysis (5\%), and diarrhea (3\%); and chest computerized tomography scans show pneumonia (Bassetti et al. 2020; Huang and Herrmann 2020). Laboratory markers include leukopenia (25\%), lymphopenia (63\%), thrombocytopenia (5\%), and high lactate dehydrogenase (73\%) (Bassetti et al. 2020). The clinical features of the COVID-19 are divided by their severity to the following forms (Wu and McGoogan 2020):

1- A mild disease that occurred in $81 \%$ of cases with no or mild pneumonia;

2- Severe disease that occurs in $14 \%$ of cases and manifests in dyspnea, respiratory frequency $\geq 30 / \mathrm{min}$, blood oxygen saturation $\leq 93 \%$, the partial pressure of oxygen/fraction of inspired oxygen ratio (the ratio between the blood pressure of the oxygen and the percentage of oxygen supplied) $<300$, lung infiltrates $>50 \%$ within 24 to $48 \mathrm{~h}$;

3- Critical disease that occurs in $5 \%$ of cases with respiratory failure, septic shock, multiple organ dysfunction, or failure.

According to the World Health Organization (WHO), the Centers for Disease Control and Prevention, and the US Food and Drug Administration (FDA), the management of COVID19 has mainly focused on infection prevention, case detection and monitoring, and supportive care. However, no specific anti-COVID-19 treatments are recommended because of the absence of evidence (Beware of Fraudulent Coronavirus Tests, Vaccines and Treatments 2020; Coronavirus Disease 2019 (COVID-19) 2020; Information for Clinicians on Therapeutic Options for COVID-19 Patients 2020). Given the urgency of the 2019-nCoV outbreak, researchers pay particular attention to the repositioning of existing antiviral agents that are approved or in development against infections caused by human immunodeficiency viruses (HIV), hepatitis $\mathrm{B}$ virus (HBV), hepatitis $\mathrm{C}$ virus (HCV), and influenza ( $\mathrm{Li}$ and De Clercq 2020). Besides, since most coronaviruses especially MERS, SARS, and COVID-19 have a similar viral structure, a similar infection pathway, and a similar structure of the $\mathrm{S}$ proteins, similar research strategies should be used for the COVID-19 (Yu et al. 2020).

The general treatment strategies include bed rest and supportive treatment, ensuring sufficient calorie and water intake, maintaining water-electrolyte balance and homeostasis, 
monitoring vital signs and respiratory support, circulation support, oxygen therapy when necessary, measuring blood routine, urine routine, C-reactive protein, and other blood biochemical indexes including liver and kidney function, myocardial enzyme spectrum, and coagulation function according to patients' conditions. Blood gas analysis and timely reexamination of chest imaging should be performed when necessary (Shen et al. 2020). Nearly all patients accept oxygen therapy, and the WHO recommends extracorporeal membrane oxygenation to patients with refractory hypoxemia (Guo et al. 2020). Nitric oxide inhalation (Chen et al. 2004) and epoprostenol inhalation, a prostacyclin with vasodilator properties (Alessandri et al. 2018; Searcy et al. 2015), are the other recommended options to treat acute respiratory distress syndrome. In vitro study revealed that nitric oxide can inhibit the replication of SARS-CoV (Åkerström et al. 2005).

At the time of writing this article, no drug is FDA approved to treat COVID-19. Some old drugs are suggested to manage COVID-19 and are being used anecdotally based on in vitro or in vivo studies; however, there are poor clinical data in supporting them. These include remdesivir, chloroquine/ hydroxychloroquine in combination with azithromycin, tocilizumab, and lopinavir/ritonavir (Coronavirus disease 2019 (COVID-19): Epidemiology, virology, clinical features, diagnosis, and prevention 2020). In March 2020, the WHO started a global mega trial of the four most promising coronavirus treatments in 10 countries called "Solidarity" in response to the COVID-19 pandemic. Remdesivir, chloroquine and hydroxychloroquine, lopinavir/ritonavir, and lopinavir/ ritonavir in combination with interferon beta are the experimental therapy currently being researched under this Solidarity Trial (WHO launches global megatrial of the four most promising coronavirus treatments 2020).

A group of Korean specialist physicians in treating COVID-19 recommended the following antiviral medication for treating older patients or patients with underlying comorbid and severe conditions. The recommended regime is lopinavir $400 \mathrm{mg} /$ ritonavir $100 \mathrm{mg}$ (Kaletra ${ }^{\circledR} 2$ tablets by mouth twice daily) or chloroquine (500 $\mathrm{mg}$ by mouth daily) or hydroxychloroquine ( $400 \mathrm{mg}$ by mouth daily), for 7 to 10 days depending on the clinical progress. Co-administration of chloroquine or hydroxychloroquine with lopinavir/ritonavir may cause serious arrhythmias and drug interaction. According to their advice, combined therapy is just recommended in very limited cases (Physicians work out treatment guidelines for coronavirus 2020).

A group of Iranian physicians and experts with experience in treating COVID-19 have developed recommendations for the treatment of hospitalized patients with COVID-19. Based on the 6th edition of this recommendation, the proposed antiviral monotherapy is chloroquine $(500 \mathrm{mg} \mathrm{q} 12 \mathrm{~h}$ at the first day followed by $250 \mathrm{mg} \mathrm{q} 12 \mathrm{~h}$, orally) or hydroxychloroquine (400 mg q12h at the first day followed by $200 \mathrm{mg} \mathrm{q} 12 \mathrm{~h}$, orally) for 7 to 14 days based on the clinical progress. In combination therapy, lopinavir/ritonavir $(400 / 100 \mathrm{mg}$ q12h, orally) is administrated with chloroquine (500 $\mathrm{mg} \mathrm{SD}$, orally) or hydroxychloroquine (400 mg SD, orally) for the first day that is followed just with lopinavir/ritonavir $(400 / 100 \mathrm{mg}$ $\mathrm{q} 12 \mathrm{~h}$, orally) for 7-14 days. In combination therapy with atazanavir/ritonavir, atazanavir/ritonavir (300/100 mg SD, orally) plus chloroquine ( $250 \mathrm{mg} \mathrm{q} 12 \mathrm{~h}$, orally) or hydroxychloroquine ( $200 \mathrm{mg}$ q12h, orally) are administrated from the first day for 7-14 days. It has been suggested that atazanavir/ritonavir has lower side effects (drug interaction with chloroquine/ hydroxychloroquine, arrhythmia, gastrointestinal intolerance) than lopinavir/ritonavir (Flowchart diagnosis and treatment of COVID 19 disease at outpatient and inpatient levels 2020).

There are two main ways in drug discovery including traditional drug development and drug repositioning. The first way that usually takes $10-15$ years needs high investments and is very expensive and the success rate is very low. The second one uses old drugs for investigating and approving new therapeutic. In contrast with the first way, it is more efficient, economical, and riskless (Xue et al. 2018).

These days, there is an emergency to investigate appropriate drug/s in COVID-19, and it seems drug repositioning be so helpful. In this review, we are mainly trying to gather findings of the old drugs-COVID19 relationship to introduce a lead for suitable therapy. However, COVID-19 therapy must be based on expert clinical experience and published literature and guidelines from major health organizations.

In this regard, the recommended dosages for proposed drugs that are currently being trialed COVID-19 based on the latest version of the WHO, 21st March 2020, are included in Table 1 (Coronavirus Disease 2019 (COVID-19) 2020). There are other interventions with limited or no clinical data that are introduced in this article.

\section{Method}

The relevant data that have been published since the start of 2020 were included by searching Google Scholar, PubMed, and valid encyclopedias. Furthermore, bibliographies of eligible articles were examined for additional relevant studies. The keywords used as search terms were "Novel Coronavirus", "COVID-19", "severe acute respiratory syndrome coronavirus 2", "SARS-CoV-2", "therapy", "treatment", "virology", "clinical future", and "pathology".

There was no restriction on the type of studies. All kinds of peer-reviewed or non-peer-reviewed research projects, reviews, letters, comments, editorials, and eBooks that have been published or being be published (in proof and press situation) were included. Non-English language studies were studied using Google Translate software. 


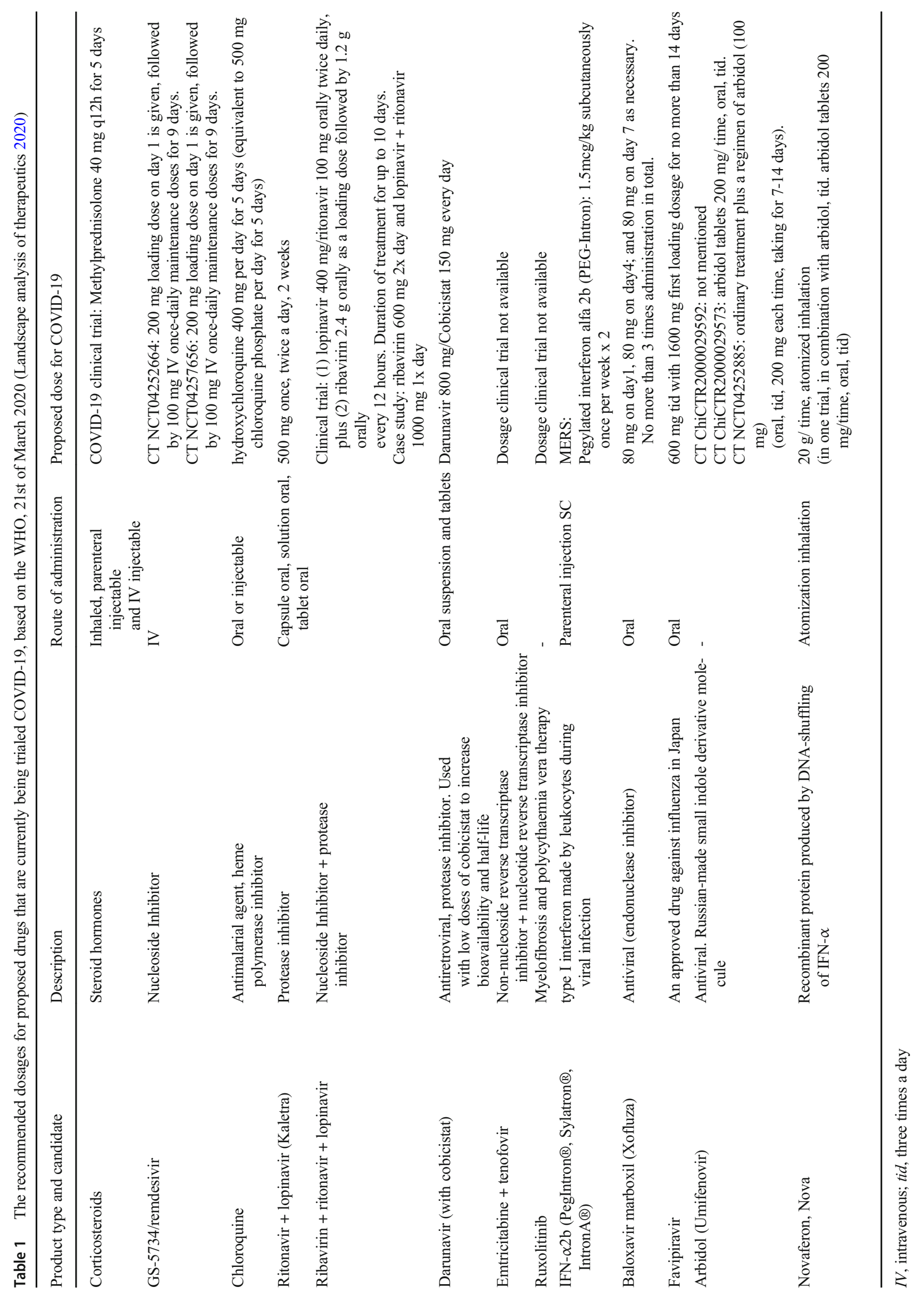




\section{Results}

\section{Antimalarial drugs}

There are strong studies that proved the efficacy of chloroquine against intracellular microorganism as well as malaria, Coxiella burnetii, and Tropheryma whipplei (Colson et al. 2020). Chloroquine or hydroxychloroquine is used against autoimmune diseases (Wang et al. 2020b) and has a worth effect against coronaviruses (Colson et al. 2020; Wang et al. 2020b). Chloroquine prescription improves pneumonia and lung imaging findings in infected patients with COVID-19. It shorts the disease course, promotes a virus-negative stage, and decreases the length of hospital stay (Gao et al. 2020). It has a good distribution into the lungs (Wang et al. 2020b).

This drug alkalizes endosomal $\mathrm{pH}$ and interferes with virus-endosome fusion that affects the virus entry or exit (Vincent et al. 2005). It has been shown the SARS-CoV spike glycoprotein mediates viral entry through $\mathrm{pH}$-dependent endocytosis (Yang et al. 2004). Chloroquine inhibits the glycosylation of ACE2 receptor expression at the cell surface (Vincent et al. 2005). It possesses immunomodulatory and anti-inflammatory impacts through many pathways including the inhibition of phospholipase A2 activity and blocking cytokine production and release (Al-Bari 2015) that may be worth full in a COVID-19 cytokine storm. It has been mentioned that the activity of hydroxychloroquine on COVID-19 is probably the same as that of chloroquine (Colson et al. 2020), although hydroxychloroquine seems to have more potent antiviral activity (Yao et al. 2020).

Since chloroquine inhibits the attachment and fusion of the virus to host cells, it could be a good prophylactic candidate against viral diseases. Some studies have shown prophylactic effects of chloroquine against SARAS-CoV in both pre- and post-exposure. A pre-exposure prophylaxis of $250-500 \mathrm{mg}$ daily and post-exposure prophylaxis at 8 $\mathrm{mg} / \mathrm{kg} /$ day for 3 days has been recommended for prophylaxis against COVID-19. However, there is no certain evidence that proves the efficacy of chloroquine in prophylaxis against COVID-19 (Chang 2020), and it has been postulated that prophylactic use of chloroquine may impair innate immune system response against this infection (Soraya 2020).

QT interval at the baseline is the most important item in evaluation chloroquine toxicity in COVID-19. Cardiovascular and dermatological problems, the exacerbation of porphyria, severe hypoglycemia, abdominal cramps, anorexia, diarrhea, nausea and vomiting, and endocrine, metabolic and gastrointestinal problems are chloroquine related side effects. Chloroquine may cause hematological and immunological abnormalities. It may raise liver enzymes and induce hypersensitivity reactions. Nervous system problems and neuromuscular, skeletal, ophthalmic, and otic difficulties are the other reported side effects. Furthermore, this medicine should be used with caution in patients with pre-existing auditory damage, G6PD deficiency, hepatic impairment, porphyria, psoriasis, and seizure disorder. Since chloroquine is the substrate of CYP2D6 (major) and CYP3A4 (major), the risk of potentially harmful drug interactions must be considered in combination therapies (Chloroquine: Drug information 2020).

\section{Anthelmintic and anti-protozoal drugs}

Niclosamide, an old anti-helminthic drug, has been reported to impose broad-spectrum antiviral properties such as SARS$\mathrm{CoV}$, MERS-CoV, Zika virus, Japanese encephalitis virus, $\mathrm{HCV}$, Ebola virus, human rhinoviruses, chikungunya virus, human adenovirus, and Epstein-Barr virus (Xu et al. 2020). $\mathrm{Wu}$ et al. (2004) reported that niclosamide was able to inhibit SARS-CoV replication and eliminate viral antigen synthesis (Wu et al. 2004). This drug stimulates autophagy in MERS$\mathrm{CoV}$ and reduces viral replication (Gassen et al. 2019). Nitazoxanide is the other antiparasitic drug that has been FDA-approved for treating Cryptosporidium and Giardia. Some studies have mentioned its broad-spectrum antiviral activity (Rossignol 2014). This drug has been suggested as an effective therapy against coronaviruses (Cao et al. 2015). Also, it has been a candidate as a new drug for the treatment of MERS (Rossignol 2016). In cells that are infected by foreign RNA, nitazoxanide amplifies host innate immune antiviral responses by triggering foreign cytoplasmic RNA sensing and the type 1 interferon axis (Jasenosky et al. 2019). In this respect, nitazoxanide may have potential against COVID-19 (Adnan Shereen et al. 2020). Headache, abdominal pain, nausea, and urine discoloration are reported in more than $2 \%$ of patients who receive nitazoxanide (Nitazoxanide: Drug information 2020).

\section{Antiviral therapy}

Based on the previous studies, it has been revealed that lopinavir/ritonavir alone or in combination with antivirals reduces the incidence and mortality of acute respiratory distress syndrome related to SARS and MERS diseases (Chu et al. 2004). Lopinavir/ritonavir inhibits HIV protease for protein cleavage and causes non-infectious and immature viral particles (Guo et al. 2020). This therapy is also has been recommended in the management of COVID-19 pneumonia but appears to have little to no effect (Cao et al. 2020a). The effectiveness of HIV protease inhibitors against COVID-19 protease enzymes is uncertain based on two reasons: the HIV proteases belong to the aspartic protease family while coronavirus proteases belong to the cysteine protease family; C2-symmetric pocket, the catalytic site of the HIV protease 
dimer (that is inhibited by anti-proteases), is absent in coronaviruses proteases ( $\mathrm{Li}$ and De Clercq 2020).

Skin rash, dyslipidemia, diarrhea, vomiting, nausea, abdominal pain, rise of liver enzymes, and upper respiratory infections have been reported in more than $10 \%$ of patients who receive lopinavir/ritonavir medication. Also, it may alter cardiovascular conduction. Lopinavir undergoes extensive metabolism via hepatic CYP3A isozymes. So, coadministration with CYP3A inducers decreases its level. Furthermore, ritonavir is a potent CYP3A inhibitor and coadministration with drugs that are metabolized with this enzyme elevates their plasma concentration (Lopinavir and ritonavir: Drug information 2020).

RNA-dependent RNA polymerase is an important enzyme in the life cycle of RNA viruses including coronaviruses, $\mathrm{HCV}$, and Zika virus. This enzyme is the target of some antiviral drugs. Sofosbuvir and ribavirin are nucleotide derivatives. They inhibit RNA-dependent RNA polymerase and are used for HCV therapy. IDX-184 is another RNAdependent RNA polymerase that is under clinical trials for HCV therapy. An in silico study proved the efficacy of remdesivir against COVID-19 RNA-dependent RNA polymerase (Elfiky 2020). Remdesivir is a novel antiviral prodrug that has been developed against the Ebola virus not only for treatment but also for prophylaxis post-exposure. It showed a broad-spectrum antiviral activity in vitro against filoviruses, arenaviruses, and coronaviruses. Remdesivir has not been approved or licensed at the time of writing this article (Warren et al. 2016). Remdesivir is metabolized into an adenosine nucleotide analog that interferes with the action of virus RNA polymerase post entry. It seems to have good inhibitory effects against COVID-19 at the cellular level (Guo et al. 2020). In a case report, remdesivir was started intravenously on day 7 in a patient with COVID-19 with no side effects (Holshue et al. 2020). Nausea, vomiting, prolonged prothrombin time, and raise of the liver enzymes have been reported with remdesivir consumption (Remdesivir (United States: Investigational agent; refer to Prescribing and Access Restrictions): Drug information 2020).

Favipiravir is a prodrug and metabolized to a nucleoside analog and inhibits the viral RNA-dependent RNA polymerase (Furuta et al. 2017) of RNA viruses such as influenza, Ebola, yellow fever, chikungunya, norovirus, enterovirus, and COVID-19. It is an approved drug against influenza in Japan (De Clercq 2019). In February 2020, this drug was being studied in Chinese randomized trials for experimental treatment of the COVID-19 (Li and De Clercq 2020).

Indinavir, atazanavir, darunavir, fosamprenavir, saquinavir, abacavir, elvitegravir, raltegravir, enzaplatovir, presatovir, maribavir, tipranavir, darunavir (Jin et al. 2020) are the other proposed antiviral drugs in threating COVID-19 (Table 2).

Medication therapy against influenza including neuraminidase inhibitors (oseltamivir, peramivir, zanamivir), and drugs like ganciclovir, acyclovir, and ribavirin, as well as methylprednisolone that were prescribed previously for treating COVID-19, are not valid now (Guo et al. 2020).

\section{Antibacterial}

Although the use of antibiotics, especially broad-spectrum types, should be avoided in patients with COVID-19, in these patients with a bacterial infection, the use of antibacterial agents is recommended (Jin et al. 2020). Proposed antimicrobial agents against community-acquired pneumonia are amoxicillin, azithromycin, or fluoroquinolones. In severe patients, all possible pathogens should be covered by empirical antibacterial treatment until the pathogenic bacteria are clarified [43]. Moxifloxacin is the best recommendation for covering mycoplasma and chlamydia (Zhang et al. 2020b). Azithromycin, a macrolide, is the best-proposed antimicrobial that has been added to the hydroxychloroquine regimen COVID-19 and induced a synergic effect on virus elimination. This combination therapy (azithromycin $500 \mathrm{mg}$ on day 1 followed by $250 \mathrm{mg}$ per day, the next 4 days and hydroxychloroquine sulfate $200 \mathrm{mg}$, three times per day during 10 days) reduced the number of viral carriages and viral carrying duration (Gautret et al. 2020). Azithromycin is an antibiotic from the macrolide group that has antiinflammatory effects (Amsden 2005; Beigelman et al. 2009; Ivetić Tkalčević et al. 2006). Furthermore, it has antiviral (Iannetta et al. 2017; Menzel et al. 2016; Schoegler et al. 2014; Schögler et al. 2014) properties. This may be a reason why adding this drug to hydroxychloroquine improved the clearance of COVID-19. In this regard, there is a need to test azithromycin as first-line therapy for COVID-19. It should be considered that both chloroquine/hydroxychloroquine (Silva et al. 2007) and azithromycin (Hancox et al. 2013) are known to prolong QTc-interval. So this combination therapy may increase the risk of cardiac side effects.

\section{Neutralizing monoclonal antibodies}

Similar to the SARS-CoV, COVID-19 attaches to the host cell ACE2 receptors through its receptor-binding motif located in the RBD of the $\mathrm{S} 1$ subunit of spike glycoprotein. Human cells expressing ACE2 are more susceptible to be infected with COVID-19 (Guo et al. 2020; Shanmugaraj et al. 2020). So, specific neutralizing monoclonal antibodies against host cell ACE2 receptors or virus receptor-binding domain in spike protein interfere with virus attachment and entry. Some monoclonal antibodies against SARS-CoV have been proposed that due to similarity with COVID-19 could be useful against this virus, too. Some of them neutralize S1 fragment and block the interaction of S1 subunit protein with cellular receptor ACE2, including 80R, CR3014, CR3022, F26G18, F26G19, m396, and 201. 1A9 monoclonal antibody binds to the S2 fragment 
Table 2 Proposed agents against COVID-19

\begin{tabular}{|c|c|c|c|}
\hline Classes & Drug & $\begin{array}{l}\text { Pharmacologic } \\
\text { category }^{\mathrm{a}}\end{array}$ & Probable anti-COVID-19 mechanism ${ }^{\mathrm{a}}$ \\
\hline \multirow[t]{3}{*}{ Antiparasitic } & Chloroquine & Antimalarials & $\begin{array}{l}\text { Alkalizes endosomal pH and interferes with virus-endosome fusion } \\
\text { (Vincent et al. 2005; Yang et al. 2004) inhibits the glycosylation of } \\
\text { ACE2 receptors (Vincent et al. 2005) } \\
\text { possesses anti-inflammatory and immunomodulatory effects by inhibi- } \\
\text { tion of phospholipase A2 activity and blocking cytokine production } \\
\text { and release (Al-Bari 2015) }\end{array}$ \\
\hline & Niclosamide & Anthelmintic & $\begin{array}{l}\text { Inhibition of S-phase kinase-associated protein } 2 \text { (SKP2) and increase of } \\
\text { autophagy (Gassen et al. 2019) }\end{array}$ \\
\hline & Nitazoxanide & $\begin{array}{l}\text { Anthelmintic, } \\
\text { anti-protozoal }\end{array}$ & $\begin{array}{l}\text { Amplifying host innate immune antiviral responses by triggering foreign } \\
\text { cytoplasmic RNA sensing and type } 1 \text { interferon axis (Jasenosky et al. } \\
\text { 2019). }\end{array}$ \\
\hline \multirow[t]{11}{*}{ Antiviral agents } & Indinavir & Anti-HIV & \multirow{5}{*}{$\begin{array}{l}\text { Protease inhibitor: inhibits cleavage of gag-pol polyprotein precursors, } \\
\text { which in turn causes the formation of immature, non-infectious viral } \\
\text { particles }\end{array}$} \\
\hline & $\begin{array}{l}\text { Ritonavir (typically used to boost } \\
\text { levels of other protease } \\
\text { inhibitors) }\end{array}$ & Anti-HIV & \\
\hline & Atazanavir & Anti-HIV & \\
\hline & Darunavir & Anti-HIV & \\
\hline & Tipranavir & Anti-HIV & \\
\hline & Fosamprenavir (prodrug) & Anti-HIV & $\begin{array}{l}\text { Protease inhibitor: prevents processing of viral gag and gag-pol } \\
\text { polyprotein precursors, resulting in the formation of immature non- } \\
\text { infectious viral particle }\end{array}$ \\
\hline & Abacavir & Anti-HIV & $\begin{array}{l}\text { Nucleotide reverse transcriptase inhibitor: guanosine analog that inhibits } \\
\text { HIV-1 reverse transcriptase by competing with dGTP as substrate, } \\
\text { which in turn inhibits viral replication }\end{array}$ \\
\hline & $\begin{array}{l}\text { Elvitegravir } \\
\text { Raltegravir }\end{array}$ & $\begin{array}{l}\text { Anti-HIV } \\
\text { Anti-HIV }\end{array}$ & $\begin{array}{l}\text { Integrase inhibitor: inhibits catalytic activity of HIV-1 integrase, in turn } \\
\text { Inhibits viral replication }\end{array}$ \\
\hline & $\begin{array}{l}\text { Remdesivir (prodrug) } \\
\text { Favipiravir (prodrug) }\end{array}$ & $\begin{array}{l}\text { research statement } \\
\text { Anti-influenza }\end{array}$ & $\begin{array}{l}\text { RNA polymerase inhibitor: metabolized into an adenosine nucleotide } \\
\text { analog that interferes with the action of virus RNA polymerase }\end{array}$ \\
\hline & Sofosbuvir (prodrug) & Anti-hepacivirus & $\begin{array}{l}\text { RNA-dependent RNA polymerase: metabolized into uridine analog } \\
\text { triphosphate, an inhibitor of HCV NS5B RNA-dependent polymer- } \\
\text { ase; suppresses viral replication }\end{array}$ \\
\hline & Ribavirin & Anti-hepacivirus & $\begin{array}{l}\text { RNA-dependent RNA polymerase: inhibits the initiation and elongation } \\
\text { of RNA fragments by inhibiting polymerase activity, inhibition of } \\
\text { viral protein synthesis }\end{array}$ \\
\hline \multirow[t]{4}{*}{$\begin{array}{l}\text { Antineoplastic } \\
\text { agents }\end{array}$} & Carfilzomib & & $\begin{array}{l}\text { Proteasome inhibitor: binds to the n-terminal threonine-containing active } \\
\text { sites of the } 20 \text { s proteasome, the proteolytic core particle within the } \\
26 \text { s proteasome, causes cell cycle arrest and apoptosis }\end{array}$ \\
\hline & Bortezomib & & $\begin{array}{l}\text { Proteasome inhibitor: reversible inhibitor of chymotrypsin-like activity } \\
\text { at the 26-s proteasome, causes cell cycle arrest and apoptosis }\end{array}$ \\
\hline & Imatinib & & $\begin{array}{l}\text { Protein-tyrosine kinase inhibitor: ABL fusion kinase inhibitor } \\
\quad(\text { Ge et al. 2020) }\end{array}$ \\
\hline & Carrizumab & & $\begin{array}{l}\text { Programmed cell death protein } 1 \text { inhibitor: activate the immune } \\
\text { system (Syn et al. 2017) }\end{array}$ \\
\hline Antibiotics & Azithromycin & Macrolide & Antiviral and anti-inflammatory effects \\
\hline \multirow{2}{*}{$\begin{array}{l}\text { Neutralizing } \\
\text { monoclonal } \\
\text { antibody }\end{array}$} & CR3022 & Research statement & $\begin{array}{l}\text { Inhibits receptor-binding domain (RBD) of S1 subunit of viral spike } \\
\text { glycoprotein (Tian et al. 2020) }\end{array}$ \\
\hline & Meplazumab & Anti-asthma & $\begin{array}{l}\text { A monoclonal antibody against CD147 and inhibit the interaction of } \\
\text { CD147 with spike protein of SARS-CoV2 }\end{array}$ \\
\hline \multirow[t]{2}{*}{ Immunoglobulins } & Human gamma globulin & Immunoglobulins & $\begin{array}{l}\text { Improving passive immunity and modulating immune inflammation } \\
\text { (Cao et al. 2020b; Zhang et al. 2020b). }\end{array}$ \\
\hline & Convalescent plasma & Research statement & $\begin{array}{l}\text { Contains neutralizing antibodies that suppress viremia } \\
\text { acceleration of infected cell clearance (Chen et al. 2020) }\end{array}$ \\
\hline Interferons & IFN $\beta$ & Interferon type 1 & immunomodulatory cytokines (Lin and Young 2014) \\
\hline
\end{tabular}


Table 2 (continued)

\begin{tabular}{llll}
\hline Classes & Drug & $\begin{array}{l}\text { Pharmacologic } \\
\text { category }^{\text {a }}\end{array}$ & Probable anti-COVID-19 mechanism $^{\text {a }}$ \\
\hline $\begin{array}{c}\text { Cytokine storm } \\
\text { inhibitors }\end{array}$ & $\begin{array}{l}\text { IFN } \alpha-2 \mathrm{a} \\
\text { Baricitinib }\end{array}$ & $\begin{array}{c}\text { Disease-modifying } \\
\text { anti-rheumatic } \\
\text { drugs }\end{array}$ & $\begin{array}{l}\text { Janus kinase (GAK) inhibitor that inhibits clathrin-mediated } \\
\text { endocytosis, cytokine release, and inflammation } \\
\text { (Richardson et al. 2020). }\end{array}$ \\
& $\begin{array}{l}\text { Tocilizumab } \\
\text { Siltuximab } \\
\text { CVL218 }\end{array}$ & $\begin{array}{l}\text { Antineoplastic } \\
\text { Research statement }\end{array}$ & $\begin{array}{l}\text { Monoclonal antibody targeting IL-6 (Zhang et al. 2020a) } \\
\text { Poly-ADP-ribose polymerase 1 (PARP1) inhibition (Ge et al. 2020) }\end{array}$ \\
\hline
\end{tabular}

Montelukast, deoxyrhapontin, polydatin, chalcone, disulfiram, carmofur, shikonin, ebselen, tideglusib, PX-12, TDZD-8, cyclosporin A, and cinanserin (Jin et al. 2020) are the other proposed agents against COVID-19 that are not included in the text and this table

$A C E 2$, angiotensin-converting enzyme 2; $d G T P$, deoxyguanosine triphosphate

${ }^{a}$ based on www.medscape.com, April 2020; www.uptodate.com, March 5, 2020, and mentioned references

of SARS-CoV and blocks the interaction of the S2 subunit protein with the cellular receptor. S230 binds to RBD and blocks the interaction of $\mathrm{S} 1$ subunit protein with cellular ACE2 receptor. 4D4 and 68 are the other proposed neutralizing monoclonal antibodies against SARS-CoV (Shanmugaraj et al. 2020). While CR3022 neutralizing antibody binds potently to both SARA-CoV and COVID-19 spike protein, some of these neutralizing antibodies including m396 and CR3014 that showed potent inhibitory against SARA-CoV spike protein does not bind to COVID-19 spike protein probably due to differences in the RBD of these tow viruses. CR3022 has a worth of potential therapy against COVID-19 (Tian et al. 2020).

It has been reported that there is a direct interaction between CD147 and spike protein of SARS-CoV2 and it mediates a role in virus infection (Wang et al. 2020a). The inhibition of this receptor by meplazumab, a monoclonal antibody against CD147, has shown a promising inhibitory effect against SAR-CoV2 both in vitro (Wang et al. 2020a) and in the clinic (Bian et al. 2020). CD147 that is presented in on epithelial cells and activated inflammatory cells induces cytokine secretion and leukocyte chemotaxis by binding with cyclophilin A. Cyclophilin A participates in T cell chemotaxis and local inflammation (Dawar et al. 2017a, b).

\section{Convalescent plasma and human gamma globulin}

Convalescent plasma and intravenous immunoglobulin (IVIg) are the other proposed strategies to improve the survival rate of patients with SARS and maybe COVID-19. A clinical study in Shanghai has shown the positive effects of convalescent plasma strategy against COVID-19 (Derebail and Falk 2020). This therapy shorted the hospital stay and decreased mortality and viral load that should be related to neutralizing antibodies from convalescent plasma that suppresses viremia. The other possible explanation for the efficacy of convalescent therapy is the acceleration of infected cell clearance (Chen et al. 2020). There is a new about the decision of the FDA in approving the use of convalescent plasma to treat critically ill patients with COVID-19 (Tanne 2020).

The administration of IVIg with low molecular weight heparin anticoagulant therapy at the early stages of COVID-19 can interrupt cytokine storm and enhance the immunity (Lin et al. 2020). A series of case studies have revealed that administration of high-dose IVIg, $0.3-0.5 \mathrm{~g} / \mathrm{kg}$, daily for 5 days, at the early stage of COVID-19, could block the progression of the disease, lymphocytopenia, and elevated inflammation markers. Although these three patients were not on the same antiviral medication, the outcome of IVIg therapy in improving passive immunity and modulating immune inflammation in COVID-19 is worth full (Cao et al. 2020b; Zhang et al. 2020b). The efficacy of immunoglobulin therapy has been revealed in SARS (Ho et al. 2004) and influenza (Liu et al. 2016) diseases, but there are not enough clinical trials on COVID-19.

Hypotension and hypertension, tachycardia and decreased heart rate, headache, fatigue, chills, pain, rigors, dizziness, injection site pruritus, sore throat and gastrointestinal problems, hematological abnormalities, the rise of liver enzymes, and neuromuscular and skeletal problems are the common side effects in more than $10 \%$ patients who received IVIg (Immune globulin (Intravenous, subcutaneous, and intramuscular): Drug information 2020).

\section{Interferon}

Interferons (IFNs) are immunomodulatory cytokines that are classified into types I, II, and III based on their receptors on the cell membrane surface. Type I of these glycoproteins, IFN alpha and beta, have been FDA approved for some viral infections (Lin and Young 2014). IFN $\beta$ has been recommended 
to be effective against COVID-19. IFN $\beta$ showed a valuable efficacy against SARS-CoV replication in tissue culture (Hart et al. 2014) and nonhuman primate model (Chan et al. 2015). It has been shown that ribavirin in the combination of IFN $\alpha$ 2a significantly improved survival at 14 days in patients infected with SARS-CoV (Omrani et al. 2014). A published article advised the administration of IFN $\alpha$ atomization inhalation ( 5 million $\mathrm{U}$ per time for adults in sterile injection water, twice a day) (Jin et al. 2020). It should be noticed that the use of nebulized drugs may distribute the virus into the air and disturb the infection control (Simonds et al. 2010).

\section{Kinases and cytokine storm in COVID-19}

As mentioned in previous sections, ACE2 is a cell surface protein expressed on the lung AT2 alveolar epithelial cells and has a main role in 2019-nCoV endocytosis and entry to the cells. Ap2-associated protein kinase 1 is one of the main promoters of clathrin-mediated endocytosis and its inhibition may disrupt the penetration of the virus into the cells and assembly of its particles. The Janus kinase (JAK) is the other regulator of the passage of the virus into the lung cells. It has been proposed that baricitinib (2 or $4 \mathrm{mg}$ once a day) by inhibition of these kinases may be useful in COVID-19 acute respiratory disease. This drug in one way blocks the virus entry and in the other way inhibits cytokine release and inflammation by inhibiting JAK1/2 (JAK-STAT signaling) (Richardson et al. 2020). Tofacitinib, baricitinib, fedratinib, and ruxolitinib all are JAK-STAT signaling inhibitors and have antiinflammatory effects; however, baricitinib is better than fedratinib and ruxolitinib due to its high affinity for Ap2-associated protein kinase 1, once-daily dosing, and acceptable side effects. It has low protein-binding properties and has no interaction with CYP drug-metabolizing enzymes and drug transporters that cause good potential for combining therapy with baricitinib COVID-19 (Richardson et al. 2020).

Upper respiratory tract infection (> 10\%), nausea, the rise of liver enzymes, dyslipidemia, anemia, thrombosis, lymphocytopenia, and an increase in creatine phosphate and serum creatinine are the reported side effects with baricitinib. It should not be used in combination with strong immunosuppressants including azathioprine or cyclosporine, other JAK inhibitors, and biological disease-modifying anti-rheumatic drugs (Baricitinib: Drug information 2020).

In the most moribund patients, $2019-\mathrm{nCoV}$ infection is also associated with a cytokine storm, which is characterized by an increase in the plasma concentrations of interleukins 2,7 , and 10 , granulocyte-colony stimulating factor, interferon- $\gamma$ inducible protein 10 , monocyte chemoattractant protein 1 , macrophage inflammatory protein 1 alpha, and tumor necrosis factor $\alpha$. In those who survive intensive care, these aberrant and excessive immune responses lead to long-term lung damage and fibrosis, cause functional disability, and reduce the quality of life (Zumla et al. 2020).

Previous studies proved the proinflammatory role of poly-ADP-ribose polymerase 1 (PARP1) in inducing inflammatory disorders especially lung injuries, acute respiratory distress syndrome, and asthma (Jagtap and Szabo 2005). PARP1 activation enhances inflammation by activation of proinflammatory cytokines, inducible nitric oxide synthase, intracellular adhesion molecule 1, cyclooxygenase 2, and NADPH oxidase as well as major histocompatibility complex class II. It promotes cytokine storm by activation of NF-kB-mediated proinflammatory signals and activation of AP-1, IL- $1 \beta$, IL- 6 , TNF- $\alpha$, and downstream cytokines and chemokines pathways. PARP1 activation results in cellular energy failure, necrosis, and cell death (Zingarelli et al. 2004). PARP1 inhibitors suppress viral replication and inhibit the ADP-ribosylation of viral core proteins, suppress the binding of nucleocapsid protein to viral RNA, and interfere with the structure packaging of the viral genome (Liu et al. 2015). Furthermore, PARP1 inhibitors reduce energy failure and suppress $\mathrm{NAD}^{+} / \mathrm{ATP}$ depletion (Larmonier et al. 2016). According to the aforementioned data, PARP1 inhibitors including CVL218 that binds to the Nterminal domain of nucleocapsid protein of COVID-19 might be a worthy candidate for treating infected people with this virus (Ge et al. 2020).

Some drugs mitigate the effects of cytokines released in response to the COVID-19 and limit lung damage in patients with severe disease. These include siltuximab, a monoclonal antibody against IL-6 that is approved for multicentric Castleman's disease (Gritti et al. 2020), and disease-modifying anti-rheumatic drugs such as tocilizumab, a monoclonal antibody targeting IL-6 (Zhang et al. 2020a); sarilumab, a recombinant humanized monoclonal antibody specific for the IL-6 (Singh et al. 2020); and anakinra, a recombinant human interleukin-1 (IL-1) receptor antagonist (Mehta et al. 2020).

Edema, pruritus, skin rash, weight gain, hyperuricemia, and upper respiratory tract infection are the most common complications in more than $10 \%$ of patients who receive siltuximab. Hypotension, headache, dyslipidemia, dermatological reactions, constipation, thrombocytopenia, hypersensitivity reactions, and renal insufficiency are the other reported side effects (Siltuximab: Drug information 2020).

More common side effects $(>10 \%)$ in patients treated with tocilizumab are dyslipidemia, the rise of liver enzymes, and injection site reaction. Cardiovascular, gastrointestinal, renal, ophthalmic, dermatologic, endocrine, and metabolic problems are the other reported complications with this drug (Tocilizumab: Drug information 2020). 
The rise of liver enzymes is common in more than $10 \%$ treated with sarilumab. Injection site pruritus, hypertriglyceridemia, and hematological abnormality are the other reported side effects (Sarilumab: Drug information 2020).

Patients who receive tocilizumab or sarilumab are at an increased risk for developing serious infections that may lead to hospitalization or death (Sarilumab: Drug information 2020; Tocilizumab: Drug information 2020).

Headache, vomiting, antibody development, infection, injection site reaction, arthralgia, nasopharyngitis, and fever are reported in more than $10 \%$ of patients treated with anakinra (Anakinra: Drug information 2020).

\section{Antineoplastic agents}

Carfilzomib, bortezomib (Jin et al. 2020), imatinib (Ge et al. 2020), and carrizumab (Zhang et al. 2020a) are proposed antineoplastic drugs against COVID-19.

Abl kinases are non-receptor tyrosine kinases that are expressed in the cytoplasm, nucleus, and mitochondria. It has been shown that Abl2 is important for the entry of SARS-CoV into the cell and Abl kinase inhibitors prevent syncytia formation by the $\mathrm{S}$ protein and block coronavirus S-mediated fusion (Sisk et al. 2018). By this background, imatinib, an Abl fusion kinase inhibitor, has been found attention as a novel candidate for COVID-19 therapy (Ge et al. 2020).

Carrizumab (camrelizumab; shr-1210) has been suggested for severe novel coronavirus pneumonia with lymphocytopenia. It is an antitumor drug that inhibits programmed cell death protein 1 (Zhang et al. 2020a). Programmed cell death protein-1 inhibitors activate the immune system (Syn et al. 2017).

Carfilzomib, bortezomib, and imatinib are considered hazardous agents (Bortezomib: Drug information 2020; Carfilzomib: Drug information 2020; Imatinib: Drug information 2020). Nausea, vomiting, fatigue, chills, headache, dyspnea, cough, fever, hypertension, peripheral edema, and hematological abnormalities are the most common reported side effects by the occurrence of more than $30 \%$ in patients who receive carfilzomib (Carfilzomib: Drug information 2020).

Peripheral neuropathy, fatigue, diarrhea, nausea, and thrombocytopenia are common complaints in more than $30 \%$ of patients who are treated with bortezomib (Bortezomib: Drug information 2020).

Edema, fatigue, pain, headache, skin rash, dermatitis, fluid retention, the rise of lactate dehydrogenase, weight gain, nausea, diarrhea, vomiting, abdominal pain, anorexia, hematological disorders, the rise of liver enzymes, muscle cramps, musculoskeletal pain and spasm, arthralgia, myalgia, periorbital edema, the rise of serum creatinine, and fever are reported in more than $30 \%$ patients who are treated with imatinib (Imatinib: Drug information 2020).

\section{Concerns and doubts}

\section{Corticosteroids}

The use of this class of drugs for severe acute respiratory distress syndrome is controversial and needs caution especially in systemic route. It has been shown that the administration of corticosteroids to SARS-infected patients decreased the degree of disease progression and dyspnea and alleviated clinical symptoms. However, this strategy had no effect on the length of hospital stay (Meng et al. 2003).

Corticosteroid therapy should not be used for the management of COVID-19-induced lung injury or shock outside of a clinical trial. Although corticosteroid treatment could have a role in suppressing lung inflammation, it was associated with an interruption in the clearance of viral RNA from respiratory tract secretions and had no positive impact on the decrease of mortality rate in critically ill patients (Russell et al. 2020). Corticosteroid therapy is accompanied by neutrophilic leukocytosis, eosinopenia, and a decrease in peripheral blood lymphocytic count especially in $\mathrm{T}$ cells (Coutinho and Chapman 2011). According to the published articles in the 1990s, the administration of corticosteroids induces a transient lymphocytopenia that peaks after $4-6 \mathrm{~h}$ and returns to the normal level after $24-48 \mathrm{~h}$. This duration depends on the potency and dose of the administrated corticosteroids (Fauci and Dale 1974; Webel et al. 1974; Yu et al. 1974). Recently, it has been proven that corticosteroid therapy induces immunosuppression predominantly by suppression of cell-mediated immunity and a minimal inhibitory effect on humoral immunity. In T cell subsets, $\mathrm{CD}^{+}{ }^{+}$is more susceptible than $\mathrm{CD} 8^{+}$(Baris et al. 2016). The viral diseases may get wild in the immunocompromised state (Rouse and Sehrawat 2010) and the body cannot fight against COVID-19.

\section{Angiotensin-converting enzyme inhibitors and angiotensin receptor blockers}

There are concerns in patients who had been treated with ACE inhibitors, e.g., captopril, or angiotensin receptor blockers, e.g., losartan. It has been shown in patients who received these medications, the expression of the ACE2 receptor was high, so the risk of infection of this virus increased (Fang et al. 2020; Zheng et al. 2020). However, there are not enough data for approving this concern, and the American Heart Association, American College of Cardiology, and the other associations recommend continuing treatment with ACE inhibitors or angiotensin receptor blockers in this population (Russell et al. 2020). 


\section{Nonsteroidal anti-inflammatory drugs}

While the possible antiviral activity of indomethacin, a nonsteroidal anti-inflammatory drug, against SARS has been reported (Amici et al. 2006), now there is a concern in the use of these pharmacological drugs in patients with COVID-19. In March 2020, the use of nonsteroidal antiinflammatory drugs such as ibuprofen as an antipyretic drug in COVID-19 has been warned and acetaminophen has been recommended. There was a report that in 4 young patients with COVID-19 and no underlying health problem, the use of ibuprofen worsened the COVID-19 symptoms. It has been speculated that its antiinflammatory properties could damp down the immune system and prolong viral shedding (Day 2020). It may reduce inflammation and fever in patients with COVID19 and diminish the utility of diagnostic signs in detecting infections. Long-term use of ibuprofen may cause gastrointestinal bleeding, fluid retention, and renal dysfunction even at therapeutic doses. In toxic doses, it may result in respiratory depression, hypotension or shock, depressed mental status, severe metabolic acidosis, severe gastrointestinal hemorrhage, life-threatening electrolyte imbalances, or arrhythmias (Ershad and Vearrier 2019).
However, there is no convincing evidence to support an association between ibuprofen and negative outcomes in COVID-19.

\section{Conclusions}

An outbreak of a COVID-19 infection has posed significant threats to international health and the economy. At present, no specific antiviral therapy has been approved for the treatment of COVID-19. In this urgent, the researchers are trying to the repositioning of existing drugs against COVID-19. Old drugs that may be effective are from different pharmacological categories, including antimalarials, anthelmintics, anti-protozoal, anti-HIVs, anti-influenza, anti-hepacivirus, antineoplastics, neutralizing antibodies, immunoglobulins, and interferons. Some of them focus on the SARS-CoV2 fusion/entry process either by inhibition of S1-mediated virus attachment or by blocking of S2-mediated virus-cell membrane fusion, and some of them interfere with viral replication. These proposed agents fight with the virus by modulating host immune response, neutralizing inflammatory cytokines, or inducing passive immunity. Convalescent plasma seems the best therapy until now in patients with COVID-19. Newly introduced

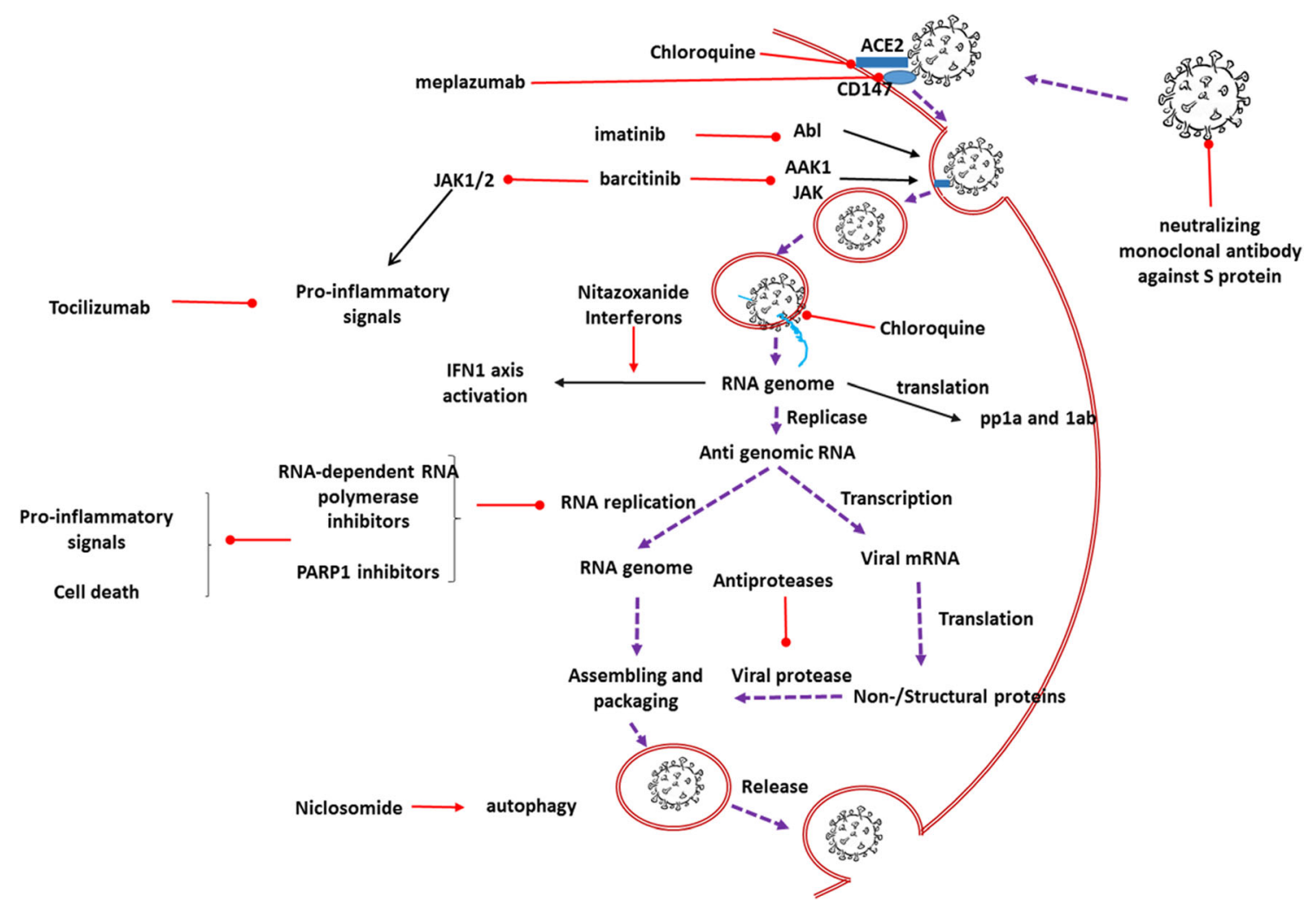

Fig. 1 Schematic represents the possible effects of proposed drugs on the severe acute respiratory syndrome coronavirus 2. AAK1, Ap2-associated protein kinase 1; Ab1, a non-receptor tyrosine kinase; ACE2, angiotensin-converting enzyme 2; IFN1, interferons type 1; JAK, Janus kinase; mRNA, messenger ribonucleic acid; PARP1, poly-ADP-ribose polymerase 1; RNA, ribonucleic acid; ppla and 1ab, protein phosphatase $1 \mathrm{a}$ and $1 \mathrm{ab} . \longrightarrow$ activator effect; $\longrightarrow$ inhibitory effect; - -ーーーー $\rightarrow$ viral cell cycle 
agents focus mainly on the host cell ACE2 receptors and S receptors on the virus (Table 2, Fig. 1).

We suggest attention on bradykinin and its neutralizing agents could be worth full. This pathway is not mentioned in recent research projects. Renin-angiotensin and kallikreinkinin systems are linked to each other through ACE. Kallikrein converts kininogen to kinins, including bradykinin, that is converted to the inactive peptide via ACE. Blocking ACE with ACE inhibitors, antihypertensive drugs, restricts the inactivation of kinins and increases the level of bradykinin (Alhenc-Gelas et al. 2019).

Bradykinin is the cause of dry cough in some patients on ACE inhibitor drugs (Fox et al. 1996). It is a proinflammatory peptide, a potent endothelium-dependent vasodilator, and a smooth muscle contractor in the bronchus. In severe cases, it may result in angioedema (Joseph and Kaplan 2005). Previously, it has been reported that the bradykinin B(2) receptor antagonist, MEN1632, and the inhibitor of tissue kallikrein, VA999024, attenuated the response to parainfluenza-3 virus-induced inflammation and airway hyperactivity (Broadley et al. 2010). It seems the feature of COVID-19 is similar to over activation of bradykinin in the body. The inhibition of this pathway is suggested as a therapy in patients infected with COVID-19.

Authors' contributions HH suggested the idea for the article; $\mathrm{HH}$ and MR provided the overall concept and framework of the manuscript; MR and MG researched and identified appropriate articles; MR wrote the manuscript; HH and AHM and MJD revised the manuscript; all authors read and approved the manuscript.

Funding information This work was supported by Clinical Research Development Units, North Khorasan University of Medical Sciences, Bojnurd, Iran, and Mashhad University of Medical Sciences, Mashhad, Iran.

\section{Compliance with ethical standards}

Conflict of interest The authors declare that they have no conflict of interest.

\section{References}

Adnan Shereen M, Khan S, Kazmi A, Bashir N, Siddique R (2020) COVID-19 infection: origin, transmission, and characteristics of human coronaviruses. J Adv Res 24:91-98. https://doi.org/10.1016/j. jare.2020.03.005

Åkerström S, Mousavi-Jazi M, Klingström J, Leijon M, Lundkvist A, Mirazimi A (2005) Nitric oxide inhibits the replication cycle of severe acute respiratory syndrome coronavirus. J Virol 79:19661969. https://doi.org/10.1128/jvi.79.3.1966-1969.2005

Al-Bari MA (2015) Chloroquine analogues in drug discovery: new directions of uses, mechanisms of actions and toxic manifestations from malaria to multifarious diseases. J Antimicrob Chemother 70:16081621. https://doi.org/10.1093/jac/dkv018
Alessandri F, Pugliese F, Ranieri VM (2018) The role of rescue therapies in the treatment of severe ARDS. Respir Care 63:92-101. https:// doi.org/10.4187/respcare.05752

Alhenc-Gelas F, Bouby N, Girolami JP (2019) Kallikrein/K1, kinins, and $\mathrm{ACE} /$ kininase II in homeostasis and in disease insight from human and experimental genetic studies. Ther Implication Front Med 6: 136. https://doi.org/10.3389/fmed.2019.00136

Amici C, di Caro A, Ciucci A, Chiappa L, Castilletti C, Martella V, Decaro N, Buonavoglia C, Capobianchi MR, Santoro MG (2006) Indomethacin has a potent antiviral activity against SARS coronavirus. Antivir Ther 11:1021-1030

Amsden GW (2005) Anti-inflammatory effects of macrolides - an underappreciated benefit in the treatment of community-acquired respiratory tract infections and chronic inflammatory pulmonary conditions? J Antimicrob Chemother 55:10-21. https://doi.org/10.1093/ jac/dkh519

Anakinra: Drug information (2020) uptodate. https://www.lib.utdo.ir/ contents/anakinra-drug-information? search=anakinra\&source $=$ panel_search_result\&selectedTitle $=1 \sim 101 \&$ usage_type $=$

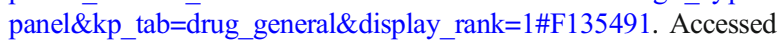
May 32020

Baricitinib: Drug information (2020) uptodate. https://www.lib.utdo.ir/ contents/baricitinib-drug-information?search=baricitinib\&source= panel_search_result\&selectedTitle $=1 \sim 19 \&$ usage_type $=$ panel\&kp $\mathrm{tab}=\overline{\mathrm{drug}}$ general\&display rank $=1 \# \mathrm{~F} 51514842$. Accessed 3 May 2020

Baris HE et al (2016) The effect of systemic corticosteroids on the innate and adaptive immune system in children with steroid responsive nephrotic syndrome. Eur J Pediatr 175:685-693. https://doi.org/10. 1007/s00431-016-2694-x

Bassetti M, Vena A, Giacobbe DR (2020) The novel Chinese coronavirus (2019-nCoV) infections: challenges for fighting the storm. Eur J Clin Investig 50:e13209. https://doi.org/10.1111/eci.13209

Beigelman A, Mikols CL, Gunsten S, Cannon CL, Walter MJ (2009) Azithromycin attenuated airway inflammation in a non-infectious mouse model of allergic asthma. J Allergy Clin Immunol 123: S263. https://doi.org/10.1016/j.jaci.2008.12.1018

Beware of Fraudulent Coronavirus Tests, Vaccines and Treatments (2020) U.S. Food and Drug Administration https://www.fda.gov/ consumers/consumer-updates/beware-fraudulent-coronavirus-testsvaccines-and-treatments. Accessed March 242020

Bian H et al (2020) Meplazumab treats COVID-19 pneumonia: an openlabelled, concurrent controlled add-on clinical trial. medRxiv 2020.2003.2021.20040691. https://doi.org/10.1101/2020.03.21. 20040691

Bortezomib: Drug information (2020) uptodate. https://www.lib.utdo.ir/ contents/bortezomib-drug-information?search= bortezomib\&source $=$ panel_search_result\&selectedTitle $=$ $1 \sim 121 \&$ usage_type=panel\&kp_tab=drug_general\&display_rank= 1\#F142110. Accessed May 32020

Broadley KJ, Blair AE, Kidd EJ, Bugert JJ, Ford WR (2010) Bradykinininduced lung inflammation and bronchoconstriction: role in parainfluenze-3 virus-induced inflammation and airway hyperreactivity. J Pharmacol Exp Ther 335:681-692. https://doi.org/10.1124/ jpet.110.171876

Cao J, Forrest JC, Zhang X (2015) A screen of the NIH clinical collection small molecule library identifies potential anti-coronavirus drugs. Antivir Res 114:1-10. https://doi.org/10.1016/j.antiviral.2014.11. 010

Cao B et al (2020a) A trial of lopinavir-ritonavir in adults hospitalized with severe Covid-19. N Engl J Med. https://doi.org/10.1056/ NEJMoa2001282

Cao W et al (2020b) High-dose intravenous immunoglobulin as a therapeutic option for deteriorating patients with Coronavirus disease 2019. Open Forum Infect Dis. https://doi.org/10.1093/ofid/ofaa102 
Carfilzomib: Drug information (2020) uptodate. https://www.lib.utdo.ir/ contents/carfilzomib-drug-information?search= Carfilzomib\&source $=$ panel_search_result\&selectedTitle $=$ $1 \sim 28 \&$ usage_type $=$ panel\&kp_tab=drug_general\&display_rank $=1 \#$ F49210440. Accessed May 32020

Chan JF et al (2015) Treatment with lopinavir/ritonavir or interferonbetalb improves outcome of MERS-CoV infection in a nonhuman primate model of common marmoset. J Infect Dis 212:1904-1913. https://doi.org/10.1093/infdis/jiv392

Chang RS, W. (2020) Repositioning chloroquine as ideal antiviral prophylactic against COVID-19 - time is now. Preprints doi:10.20944/ preprints202003.0279.v1

Chen L et al (2004) Inhalation of nitric oxide in the treatment of severe acute respiratory syndrome: a rescue trial in Beijing. Clin Infect Dis 39:1531-1535. https://doi.org/10.1086/425357

Chen L, Xiong J, Bao L, Shi Y (2020) Convalescent plasma as a potential therapy for COVID-19. Lancet Infect Dis. https://doi.org/10.1016/ S1473-3099(20)30141-9

Chloroquine: Drug information (2020) uptodate. https:/www.lib.utdo.ir/ contents/chloroquine-drug-information?search= chloroquin\&source $=$ panel_search_result\&selectedTitle $=$ $1 \sim 123 \&$ usage_type=panel\&kp_tab=drug_general\&display_rank= 1\#F54258283. Accessed May 22020

$\mathrm{Chu} \mathrm{CM}$ et al (2004) Role of lopinavir/ritonavir in the treatment of SARS: initial virological and clinical findings. Thorax 59:252-256. https:// doi.org/10.1136/thorax.2003.012658

Colson P, Rolain JM, Lagier JC, Brouqui P, Raoult D (2020) Chloroquine and hydroxychloroquine as available weapons to fight COVID-19. Int J Antimicrob Agents:105932. https://doi.org/10. 1016/j.jjantimicag.2020.105932

Coronavirus Disease 2019 (COVID-19) (2020) https://www.fda.gov/ emergency-preparedness-and-response/mcm-issues/coronavirusdisease-2019-covid-19\#mcms. Accessed March 252020

Coronavirus disease 2019 (COVID-19): Epidemiology, virology, clinical features, diagnosis, and prevention (2020) uptodate. https://www. uptodate.com/contents/coronavirus-disease-2019-covid-19\# H1354847215. Accessed Mar 23, 2020.

Coutinho AE, Chapman KE (2011) The anti-inflammatory and immunosuppressive effects of glucocorticoids, recent developments and mechanistic insights. Mol Cell Endocrinol 335:2-13. https://doi. org/10.1016/j.mce.2010.04.005

Dawar FU, Wu J, Zhao L, Khattak MNK, Mei J, Lin L (2017a) Updates in understanding the role of cyclophilin A in leukocyte chemotaxis. J Leukoc Biol 101:823-826. https://doi.org/10.1189/jlb.3RU1116$477 \mathrm{R}$

Dawar FU, Xiong Y, Khattak MNK, Li J, Lin L, Mei J (2017b) Potential role of cyclophilin A in regulating cytokine secretion. J Leukoc Biol 102:989-992. https://doi.org/10.1189/jlb.3RU0317-090RR

Day M (2020) Covid-19: ibuprofen should not be used for managing symptoms, say doctors and scientists. BMJ (Clin Res Ed) 368: m1086. https://doi.org/10.1136/bmj.m1086

De Clercq E (2019) New nucleoside analogues for the treatment of hemorrhagic fever virus infections. Chem Asian J 14:3962-3968. https:// doi.org/10.1002/asia.201900841

Derebail VK, Falk RJ (2020) ANCA-associated vasculitis — refining therapy with plasma exchange and glucocorticoids. N Engl J Med 382:671-673. https://doi.org/10.1056/NEJMe1917490

Elfiky AA (2020) Anti-HCV, nucleotide inhibitors, repurposing against COVID-19. Life Sci 248:117477. https://doi.org/10.1016/j.lfs.2020. 117477

Ershad M, Vearrier D (2019) Ibuprofen Toxicity. StatPearls Publishing LLC.,

Fang L, Karakiulakis G, Roth M (2020) Are patients with hypertension and diabetes mellitus at increased risk for COVID-19 infection? Lancet Respir Med 8:e21. https://doi.org/10.1016/s2213-2600(20) 30116-8
Fauci AS, Dale DC (1974) The effect of in vivo hydrocortisone on subpopulations of human lymphocytes. J Clin Invest 53:240-246. https://doi.org/10.1172/jci107544

Flowchart diagnosis and treatment of COVID 19 disease at outpatient and inpatient levels (2020) Islamic Republic of Iran Ministry of Health and Medical Education. http://medcare.behdasht.gov.ir/uploads/\% D9\%86\%D8\%B3\%D8\%AE\%D9\%87 \%D8\%B4\%D8\%B4\%D9\% $85 \% \mathrm{D} 9 \% 81 \% \mathrm{D} 9 \% 84 \% \mathrm{D} 9 \% 88 \% \mathrm{DA} \% 86 \% \mathrm{D} 8 \% \mathrm{~A} 7 \% \mathrm{D} 8 \% \mathrm{~B} 1 \%$ D8\%AA.pdf. Accessed April 292020

Fox AJ, Lalloo UG, Belvisi MG, Bernareggi M, Chung KF, Barnes PJ (1996) Bradykinin-evoked sensitization of airway sensory nerves: A mechanism for ACE-inhibitor cough. Nat Med 2:814-817. https://doi.org/10.1038/nm0796-814

Furuta Y, Komeno T, Nakamura T (2017) Favipiravir (T-705), a broad spectrum inhibitor of viral RNA polymerase. Proc Jpn Acad B Phys Biol Sci 93:449-463. https://doi.org/10.2183/pjab.93.027

Gao J, Tian Z, Yang X (2020) Breakthrough: chloroquine phosphate has shown apparent efficacy in treatment of COVID-19 associated pneumonia in clinical studies. Biosci Trends 14:72-73. https://doi. org/10.5582/bst.2020.01047

Gassen NC et al (2019) SKP2 attenuates autophagy through Beclin1ubiquitination and its inhibition reduces MERS-Coronavirus infection. Nat Commun 10:5770. https://doi.org/10.1038/s41467-01913659-4

Gautret $\mathrm{P}$ et al (2020) Hydroxychloroquine and azithromycin as a treatment of COVID-19: results of an open-label non-randomized clinical trial. Int J Antimicrob Agents 105949. https://doi.org/10.1016/j. ijantimicag.2020.105949

Ge Y et al (2020) A data-driven drug repositioning framework discovered a potential therapeutic agent targeting COVID-19. bioRxiv: 2020.2003.2011.986836. https://doi.org/10.1101/2020.03.11. 986836

Gritti $\mathrm{G}$ et al (2020) Use of siltuximab in patients with COVID-19 pneumonia requiring ventilatory support. medRxiv: 2020.2004.2001.20048561. https://doi.org/10.1101/2020.04.01. 20048561

Guo Y-R et al (2020) The origin, transmission and clinical therapies on coronavirus disease 2019 (COVID-19) outbreak - an update on the status. Mil Med Res 7:11. https://doi.org/10.1186/s40779-02000240-0

Hancox JC, Hasnain M, Vieweg WVR, Crouse ELB, Baranchuk A (2013) Azithromycin, cardiovascular risks, QTc interval prolongation, torsade de pointes, and regulatory issues: a narrative review based on the study of case reports. Ther Adv Infect Dis 1:155-165. https://doi.org/10.1177/2049936113501816

Hart BJ et al (2014) Interferon-beta and mycophenolic acid are potent inhibitors of Middle East respiratory syndrome coronavirus in cellbased assays. J Gen Virol 95:571-577. https://doi.org/10.1099/vir.0. 061911-0

He F, Deng Y, Li W (2020) Coronavirus Disease 2019 (COVID-19): What we know? J Med Virol. https://doi.org/10.1002/jmv.25766

Ho JC et al (2004) Pentaglobin in steroid-resistant severe acute respiratory syndrome. Int J Tuberc Lung Dis 8:1173-1179

Holshue ML et al (2020) First case of 2019 novel coronavirus in the United States. N Engl J Med 382:929-936. https://doi.org/10. 1056/NEJMoa2001191

Huang Q, Herrmann A (2020) Fast assessment of human receptorbinding capability of 2019 novel coronavirus (2019-nCoV). bioRxiv:2020.2002.2001.930537. https://doi.org/10.1101/2020.02. 01.930537

Iannetta M, Ippolito G, Nicastri E (2017) Azithromycin shows anti-zika virus activity in human glial cells. Antimicrob Agents Chemother 61:e01152-e01117. https://doi.org/10.1128/aac.01152-17

Imatinib: Drug information (2020) uptodate. https://www.lib.utdo.ir/ contents/imatinib-drug-information? search $=$ imatinib\&source $=$ panel_search_result\&selectedTitle $=1 \sim 142 \&$ usage_type $=$ 
panel\&kp_tab=drug_general\&display_rank=1. Accessed May 3 2020

Immune globulin (Intravenous, subcutaneous, and intramuscular): Drug information (2020) uptodate. www.lib.utdo.ir/contents/immuneglobulin-intravenous-subcutaneous-and-intramuscular-druginformation? search $=$ immunoglobulin\&source=panel_search result\&selectedTitle $=1 \sim 148 \&$ usage_type $=$ panel\&kp_tab $=$ drug general\&display rank=1\#F11513246. Accessed May 32020

Information for clinicians on therapeutic options for COVID-19 patients (2020) Centers for Disease Control and Prevention. https://www. cdc.gov/coronavirus/2019-ncov/hcp/therapeutic-options.html. Accessed March 212020

Ivetić Tkalčević V et al (2006) Anti-inflammatory activity of azithromycin attenuates the effects of lipopolysaccharide administration in mice. Eur J Pharmacol 539:131-138. https://doi.org/10. 1016/j.ejphar.2006.03.074

Jagtap P, Szabo C (2005) Poly (ADP-ribose) polymerase and the therapeutic effects of its inhibitors. Nat Rev Drug Discov 4:421-440. https://doi.org/10.1038/nrd1718

Jasenosky LD et al (2019) The FDA-approved oral drug nitazoxanide amplifies host antiviral responses and inhibits ebola virus. iScience 19:1279-1290. https://doi.org/10.1016/j.isci.2019.07.003

Jin Y-H et al (2020) A rapid advice guideline for the diagnosis and treatment of 2019 novel coronavirus (2019-nCoV) infected pneumonia (standard version). Mil Med Res 7:4. https://doi.org/10.1186/ s40779-020-0233-6

Joseph K, Kaplan AP (2005) Formation of bradykinin: a major contributor to the innate inflammatory response. In: Alt FW (ed) Adv Immunol, vol 86. Academic Press, pp 159-208. https://doi.org/10. 1016/S0065-2776(04)86005-X

Landscape analysis of therapeutics (2020) World Health Organization. https://www.who.int/blueprint/priority-diseases/key-action/Table of_therapeutics_Appendix_17022020.pdf?ua $=1$. Accessed $2 \overline{3}$ March 2020

Larmonier CB, Shehab KW, Laubitz D, Jamwal DR, Ghishan FK, Kiela PR (2016) Transcriptional reprogramming and resistance to colonic mucosal injury in poly (ADP-ribose) polymerase 1 (PARP1)-deficient mice. J Biol Chem 291:8918-8930. https://doi.org/10.1074/ jbc.M1 16.714386

Li G, De Clercq E (2020) Therapeutic options for the 2019 novel coronavirus (2019-nCoV). Nat Rev Drug Discov 19:149-150. https:// doi.org/10.1038/d41573-020-00016-0

Lin FC, Young HA (2014) Interferons: success in anti-viral immunotherapy. Cytokine Growth Factor Rev 25:369-376. https://doi.org/10. 1016/j.cytogfr.2014.07.015

Lin L, Lu L, Cao W, Li T (2020) Hypothesis for potential pathogenesis of SARS-CoV-2 infection-a review of immune changes in patients with viral pneumonia. Emerging microbes \& infections:1-14. https://doi.org/10.1080/22221751.2020.1746199

Lindner HA, Fotouhi-Ardakani N, Lytvyn V, Lachance P, Sulea T, Ménard R (2005) The papain-like protease from the severe acute respiratory syndrome coronavirus is a deubiquitinating enzyme. $\mathrm{J}$ Virol 79:15199-15208. https://doi.org/10.1128/jvi.79.24.1519915208.2005

Liu L et al (2015) Resolution of the cellular proteome of the nucleocapsid protein from a highly pathogenic isolate of porcine reproductive and respiratory syndrome virus identifies PARP-1 as a cellular target whose interaction is critical for virus biology. Vet Microbiol 176: 109-119. https://doi.org/10.1016/j.vetmic.2014.11.023

Liu Q, Zhou YH, Yang ZQ (2016) The cytokine storm of severe influenza and development of immunomodulatory therapy. Cell Mol Immunol 13:3-10. https://doi.org/10.1038/cmi.2015.74
Lopinavir and ritonavir: Drug information (2020) uptodate. www.lib. utdo.ir/contents/lopinavir-and-ritonavir-drug-information?search= lopinavir\% 2 Fritonavir \&source $=$ panel search result\&selectedTitle $=1 \sim 57 \&$ usage_type $=$ panel $\& \mathrm{kp} \_$tab $=$drug general\&display rank=1\#F189746. Accessed May 22020

Mehta P, McAuley DF, Brown M, Sanchez E, Tattersall RS, Manson JJ (2020) COVID-19: consider cytokine storm syndromes and immunosuppression. Lancet (London, England) 395:1033-1034. https:// doi.org/10.1016/s0140-6736(20)30628-0

Meng QH, Dong PL, Guo YB, Zhang K, Liang LC, Hou W, Dong JL (2003) Use of glucocorticoid in treatment of severe acute respiratory syndrome cases. Zhonghua yu fang yi xue za zhi [Chin J Prev Med] 37:233-235

Menzel M, Akbarshahi H, Bjermer L, Uller L (2016) Azithromycin induces anti-viral effects in cultured bronchial epithelial cells from COPD patients. Sci Rep 6:28698-28698. https://doi.org/10.1038/ srep28698

Mukherjee P, Shah F, Desai P, Avery M (2011) Inhibitors of SARS3CLpro: virtual screening, biological evaluation, and molecular dynamics simulation studies. J Chem Inf Model 51:1376-1392. https:// doi.org/10.1021/ci1004916

Niemeyer D, Mösbauer K, Klein EM, Sieberg A, Mettelman RC, Mielech AM, Dijkman R, Baker SC, Drosten C, Müller MA (2018) The papain-like protease determines a virulence trait that varies among members of the SARS-coronavirus species. PLoS Pathog 14: e1007296. https://doi.org/10.1371/journal.ppat.1007296

Nitazoxanide: Drug information (2020) uptodate. www.lib.utdo.ir/ contents/nitazoxanide-drug-information?search= nitazoxanide\&source=panel_search_result\&selectedTitle $=$ $1 \sim 28 \&$ usage_type $=$ panel\&kp_tab $=$ drug_general\&display_rank $=1 \#$ F201730. Accessed May 22020

Omrani AS et al (2014) Ribavirin and interferon alfa-2a for severe Middle East respiratory syndrome coronavirus infection: a retrospective cohort study. Lancet Infect Dis 14:1090-1095. https://doi.org/10. 1016/s1473-3099(14)70920-x

Perlman S, Netland J (2009) Coronaviruses post-SARS: update on replication and pathogenesis. Nat Rev Microbiol 7:439-450. https://doi. org/10.1038/nrmicro2147

Physicians work out treatment guidelines for coronavirus (2020) Korea Biomedical Review.http://www.koreabiomed.com/news/ articleView.html?idxno=7428. Accessed 13 Feb 2020

Remdesivir (United States: Investigational agent; refer to Prescribing and Access Restrictions): Drug information (2020) uptodate. www.lib. utdo.ir/contents/remdesivir-united-states-investigational-agentrefer-to-prescribing-and-access-restrictions-drug-information? search=Remdesivir\&source=panel_search_result\&selectedTitle $=$

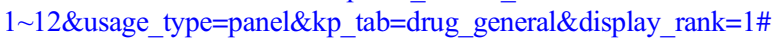
F54342497. Accessed May 22020

Richardson P, Griffin I, Tucker C, Smith D, Oechsle O, Phelan A, Stebbing J (2020) Baricitinib as potential treatment for 2019$\mathrm{nCoV}$ acute respiratory disease. Lancet (London, England) 395: e30-e31. https://doi.org/10.1016/s0140-6736(20)30304-4

Rossignol JF (2014) Nitazoxanide: a first-in-class broad-spectrum antiviral agent. Antivir Res 110:94-103. https://doi.org/10.1016/j. antiviral.2014.07.014

Rossignol JF (2016) Nitazoxanide, a new drug candidate for the treatment of Middle East respiratory syndrome coronavirus. J Infect Public Health 9:227-230. https://doi.org/10.1016/j.jiph.2016.04.001

Rouse BT, Sehrawat S (2010) Immunity and immunopathology to viruses: what decides the outcome? Nat Rev Immunol 10:514-526. https://doi.org/10.1038/nri2802

Russell CD, Millar JE, Baillie JK (2020) Clinical evidence does not support corticosteroid treatment for 2019-nCoV lung injury. 
Lancet 395:473-475. https://doi.org/10.1016/S0140-6736(20) 30317-2

Sarilumab: Drug information (2020) uptodate. https://www.lib.utdo.ir/ contents/sarilumab-drug-information?search=sarilumab\&source $=$ panel_search_result\&selectedTitle $=1 \sim 13 \&$ usage_type $=$ panel\&kp tab=drug_general\&display_rank=1\#F50136516. Accessed May 3 2020

Schoegler A et al (2014) Antiviral activity of azithromycin in cystic fibrosis airway epithelial cells. Eur Respir J 44:3450

Schögler A, Kopf BS, Edwards MR, Johnston SL, Casaulta C, Kieninger E, Jung A, Moeller A, Geiser T, Regamey N, Alves MP (2014) Novel antiviral properties of azithromycin in cystic fibrosis airway epithelial cells. Eur Respir J 45:45-439. https://doi.org/10.1183/ 09031936.00102014

Searcy RJ, Morales JR, Ferreira JA, Johnson DW (2015) The role of inhaled prostacyclin in treating acute respiratory distress syndrome. Ther Adv Respir Dis 9:302-312. https://doi.org/10.1177/ 1753465815599345

Shanmugaraj B, Siriwattananon K, Wangkanont K, Phoolcharoen W (2020) Perspectives on monoclonal antibody therapy as potential therapeutic intervention for Coronavirus disease-19 (COVID-19). Asian Pac J Allergy Immunol. https://doi.org/10.12932/ap200220-0773

Shen K et al (2020) Diagnosis, treatment, and prevention of 2019 novel coronavirus infection in children: experts' consensus statement. World J Pediatr. https://doi.org/10.1007/s12519-020-00343-7

Siltuximab: Drug information (2020) uptodate. https://www.lib.utdo.ir/ contents/siltuximab-drug-information?search=Siltuximab\&source $=$ panel_search_result\&selectedTitle=1 6\&usage type=panel\&kp tab=drug_general\&display_rank=1\#F24801298. Accessed May 3 2020

Silva JA, Silva MB, Skare TL (2007) Chloroquine and QTc interval. Clin Exp Rheumatol 25:795

Simonds AK et al (2010) Evaluation of droplet dispersion during noninvasive ventilation, oxygen therapy, nebuliser treatment and chest physiotherapy in clinical practice: implications for management of pandemic influenza and other airborne infections. Health Technol Assess (Winchester, England) 14:131-172. https://doi.org/10.3310/ hta14460-02

Singh AK, Singh A, Shaikh A, Singh R, Misra A (2020) Chloroquine and hydroxychloroquine in the treatment of COVID-19 with or without diabetes: a systematic search and a narrative review with a special reference to India and other developing countries. Diabetes Metab Syndr 14:241-246. https://doi.org/10.1016/j.dsx.2020.03.011

Sisk JM, Frieman MB, Machamer CE (2018) Coronavirus S proteininduced fusion is blocked prior to hemifusion by $\mathrm{Abl}$ kinase inhibitors. J Gen Virol 99:619-630. https://doi.org/10.1099/jgv.0.001047

Soraya H (2020) Prophylactic use of chloroquine may impair innate immune system response against SARS-Cov-2. Pharm Sci. https://doi. org/10.34172/PS.2020.29

$\mathrm{Su} \mathrm{Z}, \mathrm{Wu}$ Y (2020) A multiscale and comparative model for receptor binding of 2019 novel coronavirus and the implication of its life cycle in host cells. bioRxiv 2020.2002.2020.958272. https://doi. org/10.1101/2020.02.20.958272

Syn NL, Teng MWL, Mok TSK, Soo RA (2017) De-novo and acquired resistance to immune checkpoint targeting. Lancet Oncol 18:e731e741. https://doi.org/10.1016/s1470-2045(17)30607-1

Tanne JH (2020) Covid-19: FDA approves use of convalescent plasma to treat critically ill patients. BMJ (Clin Res ed) 368:m1256. https:// doi.org/10.1136/bmj.m1256

Tian X et al (2020) Potent binding of 2019 novel coronavirus spike protein by a SARS coronavirus-specific human monoclonal antibody. bioRxiv:2020.2001.2028.923011. https://doi.org/10. $1101 / 2020.01 .28 .923011$

Tocilizumab: Drug information (2020) uptodate. https://www.lib.utdo.ir/ contents/tocilizumab-drug-information?search= tocilizumab\&source $=$ panel_search_result\&selectedTitle $=$ $1 \sim 111 \&$ usage_type $=$ panel\&kp_tab=drug_general\&display_rank= 1\#F9773705. Accessed May 32020

Vincent MJ, Bergeron E, Benjannet S, Erickson BR, Rollin PE, Ksiazek TG, Seidah NG, Nichol ST (2005) Chloroquine is a potent inhibitor of SARS coronavirus infection and spread. Virol J 2:69. https://doi. org/10.1186/1743-422X-2-69

Wang K et al (2020a) SARS-CoV-2 invades host cells via a novel route: CD147-spike protein. bioRxiv 2020.2003.2014.988345. https://doi. org/10.1101/2020.03.14.988345

Wang M et al (2020b) Remdesivir and chloroquine effectively inhibit the recently emerged novel coronavirus $(2019-\mathrm{nCoV})$ in vitro. Cell Res 30:269-271. https://doi.org/10.1038/s41422-020-0282-0

Warren TK et al (2016) Therapeutic efficacy of the small molecule GS5734 against Ebola virus in rhesus monkeys. Nature 531:381-385. https://doi.org/10.1038/nature 17180

Webel ML, Ritts RE Jr, Taswell HF, Danadio JV Jr, Woods JE (1974) Cellular immunity after intravenous administration of methylprednisolone. J Lab Clin Med 83:383-392

WHO launches global megatrial of the four most promising coronavirus treatments (2020) Science. https://www.sciencemag.org/news/ 2020/03/who-launches-global-megatrial-fourmost-promisingcoronavirus-treatments. Accessed 22 Mar 2020

Wu Z, McGoogan JM (2020) Characteristics of and important lessons from the coronavirus disease 2019 (COVID-19) outbreak in China: summary of a report of 72314 cases from the Chinese Center for Disease Control and Prevention. Jama. https://doi.org/10.1001/ jama.2020.2648

Wu CJ et al (2004) Inhibition of severe acute respiratory syndrome coronavirus replication by niclosamide. Antimicrob Agents Chemother 48:2693-2696. https://doi.org/10.1128/aac.48.7.2693-2696.2004

Wu A et al (2020) Genome composition and divergence of the novel coronavirus (2019-nCoV) originating in China. Cell Host Microbe. https://doi.org/10.1016/j.chom.2020.02.001

Xu J, Shi PY, Li H, Zhou J (2020) Broad spectrum antiviral agent niclosamide and its therapeutic potential. ACS Infect Dis. https:// doi.org/10.1021/acsinfecdis.0c00052

Xue H, Li J, Xie H, Wang Y (2018) Review of drug repositioning approaches and resources. Int J Biol Sci 14:1232-1244. https://doi.org/ $10.7150 /$ ijbs. 24612

Yang ZY et al (2004) pH-dependent entry of severe acute respiratory syndrome coronavirus is mediated by the spike glycoprotein and enhanced by dendritic cell transfer through DC-SIGN. J Virol 78: 5642-5650. https://doi.org/10.1128/jvi.78.11.5642-5650.2004

Yao X et al (2020) In vitro antiviral activity and projection of optimized dosing design of hydroxychloroquine for the treatment of severe acute respiratory syndrome coronavirus 2 (SARS-CoV-2). Clin Infect Dis. https://doi.org/10.1093/cid/ciaa237

Yu DT, Clements PJ, Paulus HE, Peter JB, Levy J, Barnett EV (1974) Human lymphocyte subpopulations. Effect of corticosteroids. J Clin Invest 53:565-571. https://doi.org/10.1172/jci107591

Yu F, Du L, Ojcius DM, Pan C, Jiang S (2020) Measures for diagnosing and treating infections by a novel coronavirus responsible for a pneumonia outbreak originating in Wuhan, China. Microbes Infect 22:74-79. https://doi.org/10.1016/j.micinf.2020.01.003

Zhang Q, Wang Y, Qi C, Shen L, Li J (2020a) Clinical trial analysis of 2019-nCoV therapy registered in China. J Med Virol. https://doi. org/10.1002/jmv. 25733 
Zhang Z, Li X, Zhang W, Shi ZL, Zheng Z, Wang T (2020b) Clinical features and treatment of 2019-nCov pneumonia patients in Wuhan: report of a couple cases. Virol Sin. https://doi.org/10.1007/s12250020-00203-8

Zheng Y-Y, Ma Y-T, Zhang J-Y, Xie X (2020) COVID-19 and the cardiovascular system. Nat Rev Cardiol. https://doi.org/10.1038/ s41569-020-0360-5

Zhou P et al (2020) A pneumonia outbreak associated with a new coronavirus of probable bat origin. Nature 579:270-273. https://doi.org/ 10.1038/s41586-020-2012-7

Zingarelli B, Hake PW, Burroughs TJ, Piraino G, O'Connor M, Denenberg A (2004) Activator protein-1 signalling pathway and apoptosis are modulated by poly (ADP-ribose) polymerase- 1 in experimental colitis. Immunology 113:509-517. https://doi.org/10. 1111/j.1365-2567.2004.01991.x

Zumla A, Chan JF, Azhar EI, Hui DS, Yuen KY (2016) Coronaviruses drug discovery and therapeutic options. Nat Rev Drug Discov 15: 327-347. https://doi.org/10.1038/nrd.2015.37

Zumla A, Hui DS, Azhar EI, Memish ZA, Maeurer M (2020) Reducing mortality from 2019-nCoV: host-directed therapies should be an option. Lancet 395:e35-e36. https://doi.org/10.1016/S01406736(20)30305-6

Publisher's note Springer Nature remains neutral with regard to jurisdictional claims in published maps and institutional affiliations. 